\title{
miR-145 suppresses embryo-epithelial juxtacrine communication at implantation by modulating maternal IGF1R
}

\author{
Youn-Jung Kang ${ }^{1,2,3, *, \S}$, Miranda Lees ${ }^{1,2, \S}$, Laura C. Matthews ${ }^{4}$, Susan J. Kimber ${ }^{5}$, Karen Forbes ${ }^{1,2, \pm, \uparrow}$ and \\ John D. Aplin ${ }^{1,2,9}$
}

\begin{abstract}
Successful implantation requires the synchronization of viable embryonic development with endometrial receptivity. The mechanisms allowing for the initiation of crosstalk between the embryo and the endometrium remain elusive; however, recent studies have revealed that there are alterations in endometrial microRNAs (miRs) in women suffering repeated implantation failure and that one of the altered miRs is miR-145. We assessed the role of miR-145 and its target IGF1R, in early implantation. miR-145 overexpression and IGF1R knockdown were achieved in Ishikawa endometrial cells. Quantitative PCR, western blotting and 3'UTR luciferase reporter assays confirmed that IGF1R is a direct target of miR-145 in the endometrium. Attachment of mouse embryos or IGF1-coated beads to endometrial epithelial cells was used to study the effects of altered miR-145 and/or IGF1R expression on early implantation events. miR-145 overexpression or specific reduction of IGF1R impaired attachment in both cases. An IGF1R target protector prevented the miR-145-mediated reduction in IGF1R and reversed the effect of miR-145 overexpression on attachment. The data demonstrate that miR-145 influences embryo attachment by reducing the level of IGF1R in endometrium.
\end{abstract}

KEY WORDS: IGF1R, Endometrium, Implantation, Embryo, miR-145, miRNA

\section{INTRODUCTION}

Implantation failure is a major cause of infertility in the developed world (Margalioth et al., 2006) and a continuing problem in assisted reproduction (Ferraretti et al., 2012), where success rates after IVF still only lie at around $25 \%$ and the rate of embryonic loss at the implantation stage is higher than the rate of

${ }^{1}$ Maternal and Fetal Health Research Centre, Institute of Human Development, University of Manchester, Manchester M13 9WL, UK. ${ }^{2}$ St Mary's Hospital, Central Manchester University Hospitals NHS Foundation Trust, Manchester Academic Health Science Centre, Manchester M13 9WL, UK. ${ }^{3}$ Nuffield Department of

Obstetrics and Gynaecology, University of Oxford, Level 3, Women's Centre,

John Radcliffe Hospital, Headington, Oxford OX3 9DU, UK. ${ }^{4}$ Centre for

Endocrinology \& Diabetes, Institute of Human Development, University of

Manchester, AV Hill Building, Oxford Road, Manchester, M13 9PT, UK. ${ }^{5}$ Faculty of

Life Sciences, Michael Smith Building, Oxford Road, Manchester, M13 9PT, UK.

*Present address: Beth Israel Deaconess Medical Center/Harvard Medical

School, 330 Brookline Avenue, Boston, MA, 02115, USA. ¥Present address:

Division of Reproduction and Early Development, Leeds Institute of

Cardiovascular and Metabolic Medicine (LICAMM), University of Leeds, Leeds

LS2 9JT, UK.

$\S$ These authors contributed equally to this work

`Authors for correspondence (k.a.forbes@leeds.ac.uk;

john.aplin@manchester.ac.uk)

Received 29 September 2014; Accepted 12 December 2014 later fetal loss (de los Santos et al., 2003; de Mouzon et al., 2010). Although definitions of recurrent implantation failure (RIF) vary (Coughlan et al., 2014; Polanski et al., 2014), it is clear that embryo transfer commonly leads to a biochemical pregnancy [human chorionic gonadotropin (hCG) detected but no embryonic sac] or no detectable pregnancy at all. RIF appears distinct from recurrent miscarriage; that is, there is a group of women in whom pregnancy repeatedly fails very early on (Koot et al., 2011). This might be accounted for by the repeated transfer of karyotypically abnormal embryos or, alternatively, by a lack of adequate receptivity in the endometrium.

Prior to the arrival of an embryo, the action of steroid hormones on endometrium produces a period of receptivity, referred to as the 'window of implantation' (Cha et al., 2012; Psychoyos, 1974; Tabibzadeh et al., 1987). In humans, this lasts from approximately day 20 to day 24 of the menstrual cycle (Achache and Revel, 2006; Aplin, 2000; Aplin and Kimber, 2004; Bergh and Navot, 1992; Enders, 1989; Psychoyos, 1974). After the endometrium becomes receptive and the embryo reaches the blastocyst stage, the embryo must initiate interaction with the luminal epithelium (Dey, 2004; Nimbkar-Joshi et al., 2009; Rashid et al., 2011; Tabibzadeh et al., 1987). A cascade of physiological and molecular events is then triggered, leading to the establishment of a stable maternal-conceptus relationship (Garrido-Gomez et al., 2010; Simón et al., 2000a; Simón et al., $2000 \mathrm{~b}$ ). It is estimated that half of implantation failures in women suffering from RIF after embryo transfer are due to defects in endometrial receptivity. However, little is known about the molecular events that establish receptivity prior to implantation, especially in humans (Aplin, 2007), or the mechanisms that mediate early dialogue between the embryo and endometrium (Bazer et al., 2009; Cakmak and Taylor, 2011; Salker et al., 2011).

Analysis of temporal changes in biopsies of endometrial tissue taken from different stages of the menstrual cycle and from patients with RIF has been suggested as a means by which to identify candidate molecules that are involved in mediating endometrial receptivity. 'Omics' technologies have allowed the identification of candidate mediators of adhesion (Singh and Aplin, 2014), menstrual-cycle-related alterations and illuminated adverse effects of some ovarian stimulation regimes (Altmäe et al., 2014; Aplin and Singh, 2008; Domínguez et al., 2009; Rai et al., 2010; Vilella et al., 2013), but these have not yet been exploited in new medical treatments to improve endometrial receptivity.

MicroRNAs (miRs) suppress gene expression at the posttranscriptional level by blocking target mRNA translation or selecting mRNA for degradation (Bartel, 2004). It has been suggested that they are involved in mediating endometrial 
responses to maternal hormones and regulating the transition from the proliferative into the secretory phase (Kuokkanen et al., 2010). Endometrial miRNA profiles are altered in women suffering from endometriosis - a disease associated with infertility (Burney et al., 2009; Burney et al., 2007) - and in patients with RIF (Revel et al., 2011), suggesting that they might be important regulators of endometrial receptivity and thus implantation success.

Among the most dysregulated miRs within the endometrium of women with RIF is miR-145 (Revel et al., 2011). We have recently shown that miR-145 is important in mediating placental growth in humans (Farrokhnia et al., 2014; Forbes et al., 2012). One of the targets of miR-145 is the type-1 insulin-like growth factor receptor (IGF1R) (La Rocca et al., 2009; Law et al., 2012) and IGF1R mRNA has been previously shown to be present in endometrium (Zhou et al., 1994). Despite this, to our knowledge, its role in regulating human endometrial receptivity or implantation remains to be explored.

We hypothesized that altered expression of miR-145 contributes to the initial maternal-embryo interaction during the window of implantation by regulating gene expression in endometrial epithelial cells. To explore this, we manipulated miR-145 expression in endometrial cells and assessed embryo attachment using in vitro models (Kang et al., 2014). We examined IGF1R as a potential target of miR-145 in epithelium and the effect of altering the level of the receptor on embryo attachment. We suggest that IGF1R plays a role in implantation.

\section{RESULTS}

\section{miR-145 overexpression prevents embryo attachment}

Following transfection with miR-145-specific miR mimics, levels of miR-145 were significantly increased compared to control $(10-100 \mathrm{nM} ; \quad P<0.05, \quad n=6) \quad$ (Fig. 1A). The transfection procedure alone or the presence of a non-targeting miR mimic had no effect on levels of miR-145. All subsequent experiments were undertaken using both $50 \mathrm{nM}$ and $100 \mathrm{nM}$ of the mimetic. A total of 18 5-day-old mouse embryos were transferred to Ishikawa cells $48 \mathrm{~h}$ after transfection with miR-145. The stability of embryo attachment was measured after a further $24 \mathrm{~h}$ of coculture (Carver et al., 2003). Displacement or disruption of cells surrounding the attached mouse embryos, and marked outgrowth of trophoblast cells were observed in the controls, whereas embryos attached to miR-145-transfected cells retained the blastocyst morphology including a clearly defined cavity (Fig. 1B). Embryo attachment stability was measured using a five point scale: 1 , floating; 2 , weakly attached but detached after tapping; 3, weakly attached but stuck at the attachment site after tapping; 4, stably attached; and 5, stably attached and showed outgrowth (Kang et al., 2014). This quantification revealed that embryos on control cells had attachment scores of 3-5 compared to scores of 1-2 for miR-145-treated cells. Control cells without any transfection, and mock or pre-miR transfected cells were significantly $(P=0.0097)$ more stably attached than on miR-145 transfected cells (Fig. 1C).

\section{miR-145 regulates IGF1R expression in Ishikawa cells}

miR-145 has multiple targets, one of which is IGF1R, which is present in the human endometrium (Zhou et al., 1994). Ishikawa cells were transfected with a miR-145 mimic and the effect on IGF1R mRNA and protein monitored using quantitative real-time PCR (QPCR) and western blotting, respectively. Despite no changes in IGF1R mRNA (Fig. 2A),

\section{A miR-145 overexpression}
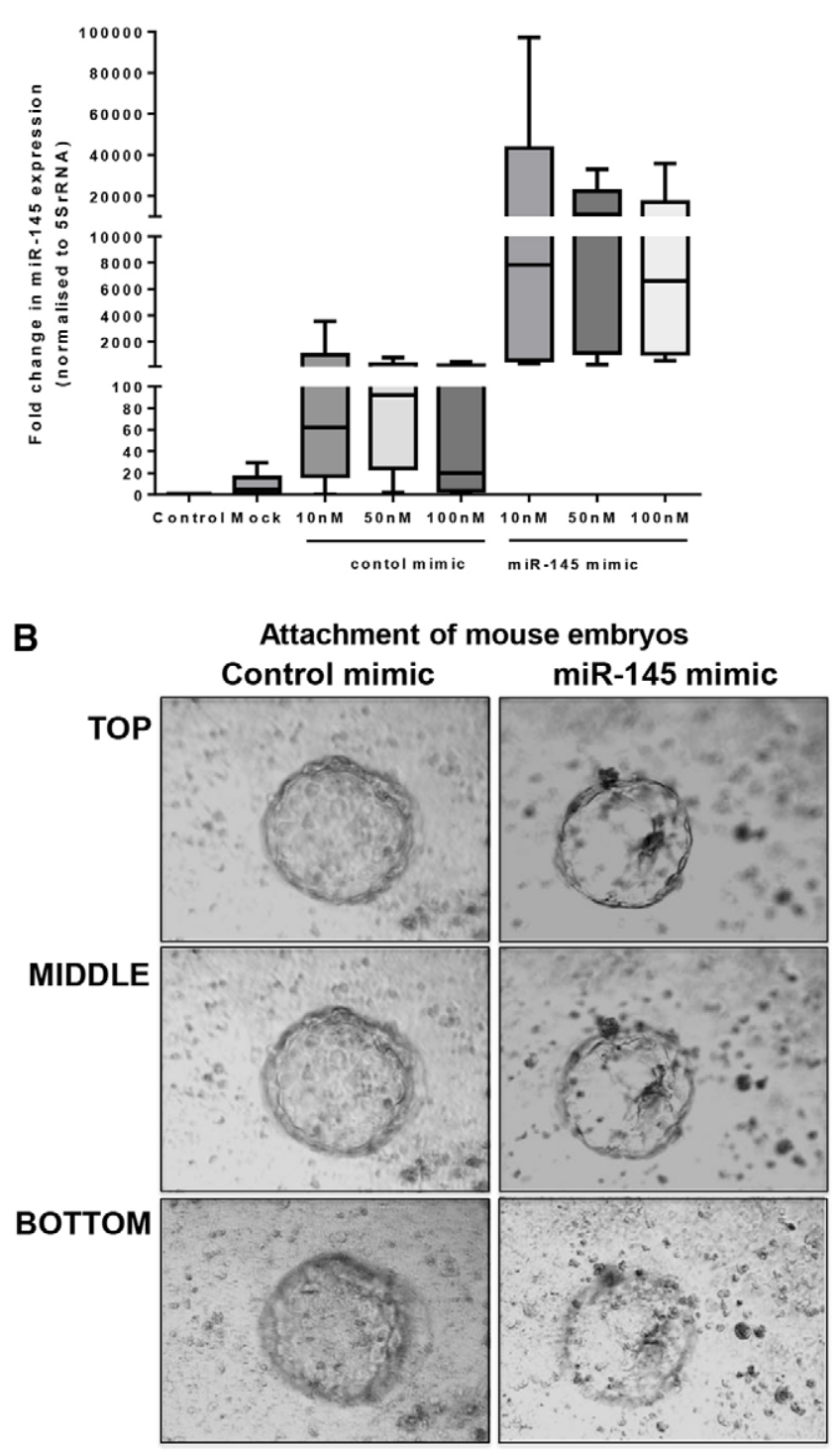

C

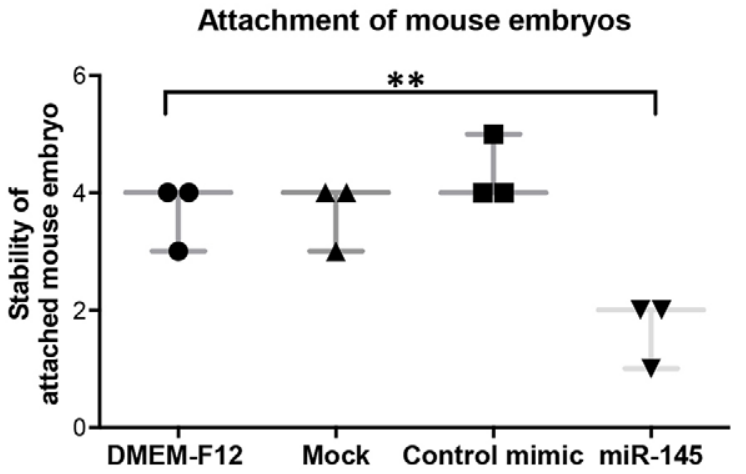

Fig. 1. See next page for legend.

IGF1R protein expression was reduced $48 \mathrm{~h}$ following miR-145 overexpression (Fig. 2B).

To determine whether miR-145 directly binds to IGF1R in these cells, the highly conserved predicted binding site within the IGF1R 3'UTR (3804-3810 bp) was cloned into the 
Fig. 1. miR-145 regulates embryo attachment. Ishikawa cells were mocktransfected (mock) or transfected with a non-targeting control miR-mimic (control mimic) or a miR-145 mimic (10-100 nM). (A) Overexpression of miR145 was confirmed by QPCR. ${ }^{* * *} P<0.0001$ ( $n=6$, Wilcoxon Signed Rank test in comparison to control). The box represents the 25-75th percentiles, and the median is indicated. The whiskers show the range. (B) Phasecontrast images at three z-planes of mouse embryos attached to Ishikawa endometrial cells following transfection with miR-mimics. Images were taken after $24 \mathrm{~h}$ of co-culture (representative of $n=15$ ). (C) The stability of mouse embryo attachment to Ishikawa cells was assessed as previously described (Kang et al., 2014). Data are expressed as median and interquartile range. ${ }^{* *} P<0.01(n=3$, Kruskal-Wallis test with Dunn's multiple comparison).
pmiR-GLO luciferase reported vector alone or in combination with miR-145 mimics (Fig. 2C). As expected, luciferase activity was detected under all conditions in the presence of a non-targeting mimic. In the presence of the miR-145 mimic there was an $81 \%$ reduction in luciferase activity of the IGF1R 3804-3810 vector (Fig. 2C; $P=0.0079, n=5$ ). Cotransfection of the miR-145 mimic with the empty pmiR-GLO (empty vector) or the scrambled IGF1R 3'UTR vector (IGF1R $\Delta 3804-3810)$ did not alter luciferase activity. This indicates that miR-145 binds directly to the 3804-3810 region in IGF1R 3'UTR.
A

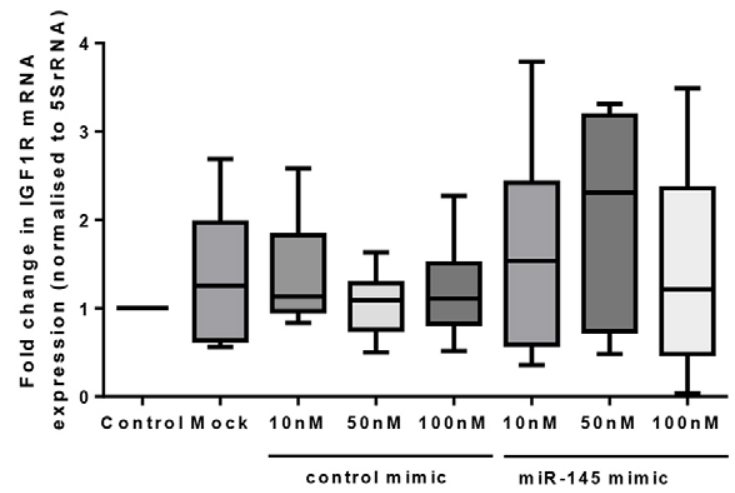

B
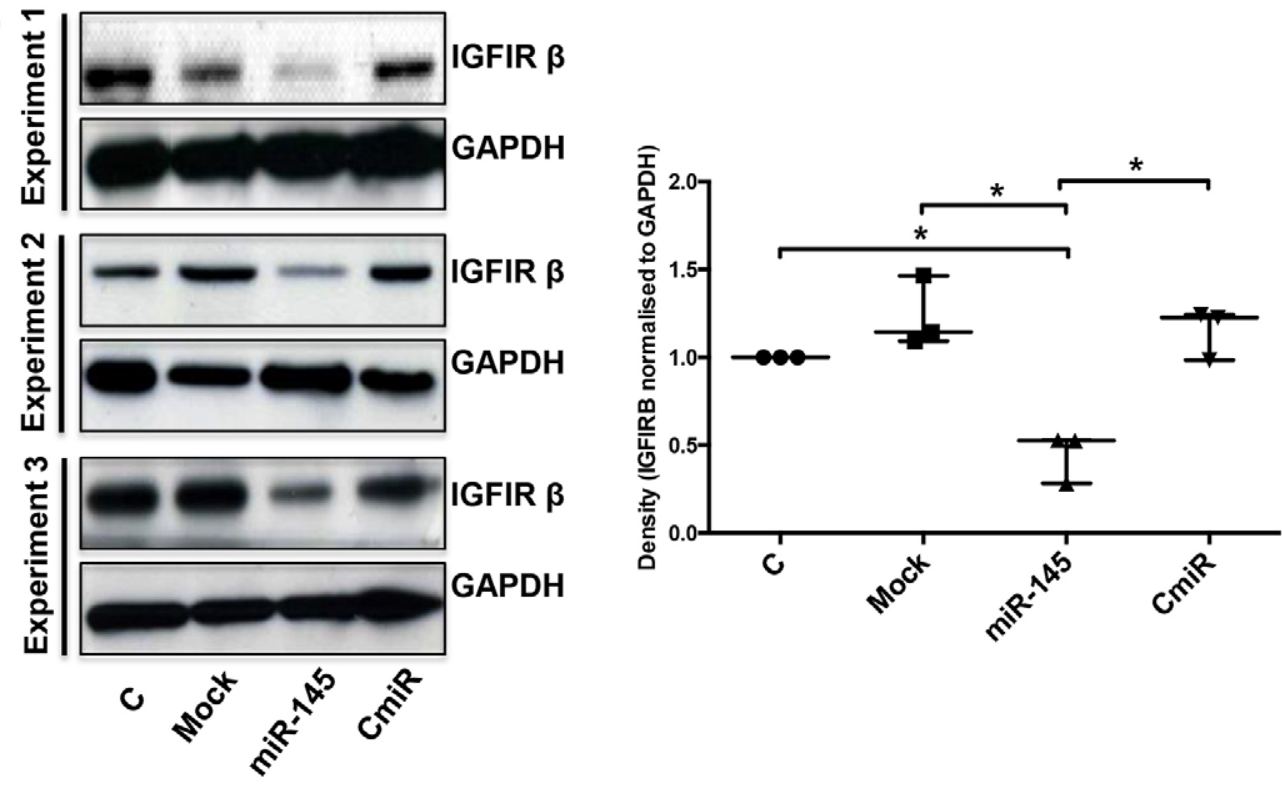

C

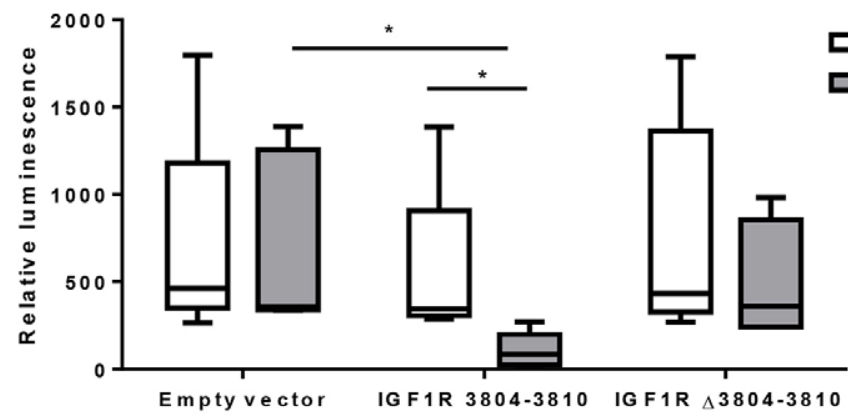

Fig. 2. miR-145 regulates IGF1R expression. $(A, B)$ Ishikawa cells were transfected with a non-targeting (control mimic) or miR-145 specific miR mimic (10-100 $\mathrm{nM}$ ) and appropriate controls. (A) IGF1R mRNA expression was quantified by QPCR and normalized to $\beta$-actin mRNA. Data are presented as a fold change in comparison to control $(n=6)$. There is no observed change in mRNA expression. (B) Western blotting revealed decreased expression of IGF1R protein following transfection with miR-145 mimic at $100 \mathrm{nM}$ in comparison to control. Blots were stripped and re-probed with anti-GAPDH antibodies to correct for protein loading. Blots represent at least three individual sample sets. Data are expressed as median and interquartile range.

(C) Synthetic oligonucleotides for the specific (IGF1R 3804-3810) or mutated (IGF1R $\Delta 3804-3810$ ) miR145-binding sites in IGF1R mRNA, were cloned in to pmiR-GLO luciferase reporter vector and transfected in to Ishikawa cells in the presence of non-targeting (control mimic) or miR-145 specific miRmimics. Direct interaction between miR-145 and IGF1R in Ishikawa cells was assessed by luciferase reporter assay. Levels of firefly luciferase were assessed and normalized to levels of $\beta$-galactosidase. ${ }^{*} P<0.05(n=5$, Kruskal-Wallis test). For $A$ and $C$, the box represents the 25-75th percentiles, and the median is indicated. The whiskers show the range. 


\section{IGF1R is upregulated in the endometrial epithelium at the time of endometrial receptivity}

Previous studies have localized IGF1R mRNA in vivo to endometrial luminal and glandular epithelium (Zhou et al., 1994) but localization of IGF1R protein has not been reported. We examined IGF1R protein expression in human endometrium at different time points in the menstrual cycle (proliferative, days 7-17; early secretory, days 18-20; mid-secretory, days 20-21; late secretory, days 26-27). IGF1R was detectable at all stages (Fig. 3A,C,E,G). Some regional variation in epithelial staining was evident, but staining intensity was highest at the endometrial luminal epithelium during the mid and late secretory stages (Fig. 3E,G).

\section{miR-145 overexpression prevents IGF1-loaded bead attachment}

Multiple factors are released from embryos and/or are present in the uterine fluid, including the predominant ligand for
IGF1R, IGF1 (Kane et al., 1997). To demonstrate functional receptor at the apical epithelial surface, and to assess the possibility that IGF1R might contribute directly to an adhesive interaction at the cell surface, we examined attachment to confluent Ishikawa cells of IGF1-coated embryo-sized beads (Kang et al., 2014). Attachment of beads was assessed by counting the number stably attached against the total number of beads originally transferred (Kang et al., 2014). Following overexpression of miR-145 (48 h), IGF1 or BSA (negative control)-loaded beads were transferred and, $24 \mathrm{~h}$ later, attachment was assessed. $52 \%$ of beads carrying IGF1 were stably attached under control conditions (Fig. 4) and following miR-145 overexpression this was reduced to $17 \%(100 \mathrm{nM}$; $P<0.01 ; n=5)$. Levels of attachment were unaffected by the transfection procedure (mock) or in the presence of nontargeting miR (control mimic). Levels of attachment of BSAcoated beads were low and unaffected by miR-145 overexpression.
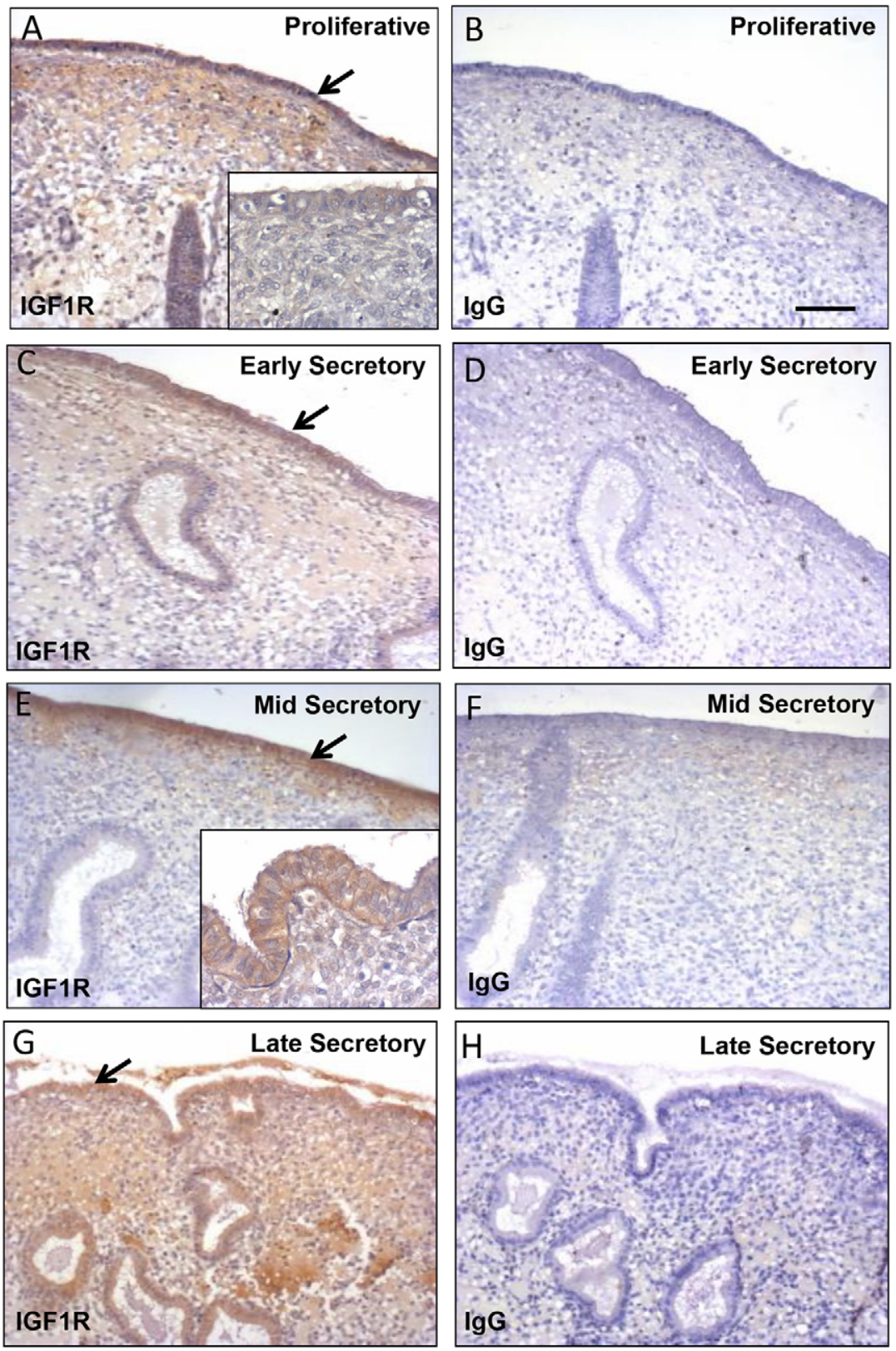
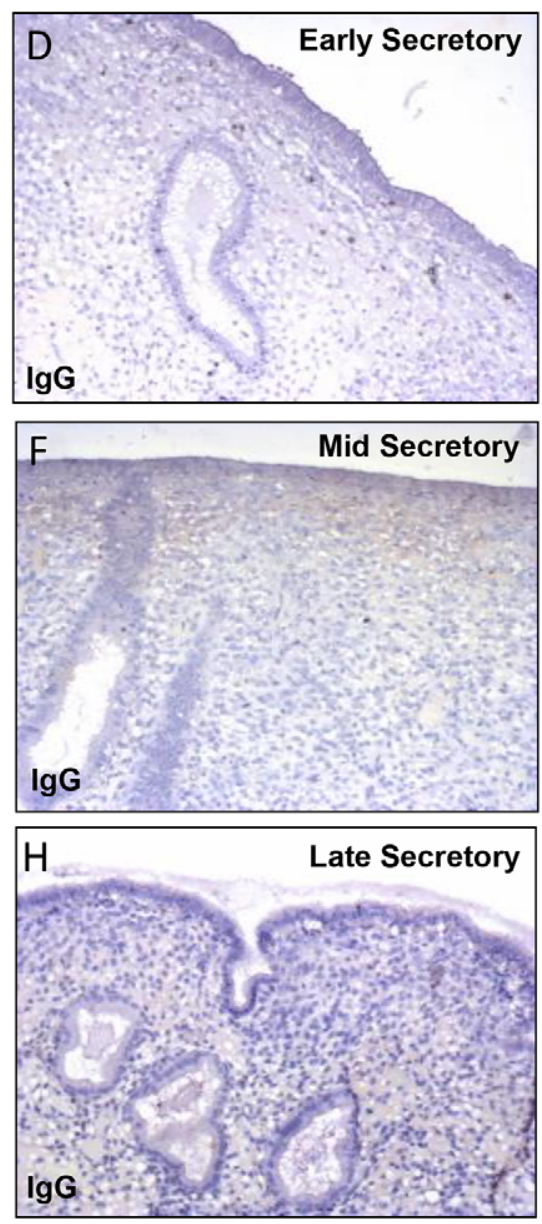

Fig. 3. IGF1R is present in endometrial luminal epithelium at the receptive phase. Endometrial biopsies obtained from different stages of the menstrual cycle were stained for IGF1R. Mouse IgG was included as a negative control in adjacent sections. IGF1R is expressed in the endometrium throughout the menstrual cycle but appears to be primarily localized to the endometrial epithelium (arrows) in the mid-late secretory stages, the former representing the time of optimal endometrial receptivity. Insets in A and $E$ show luminal epithelium at higher magnification. Each image is representative of at least three tissue samples. Scale bar: $75 \mu \mathrm{m}$. Insets are $75 \mu \mathrm{m}$ across. 


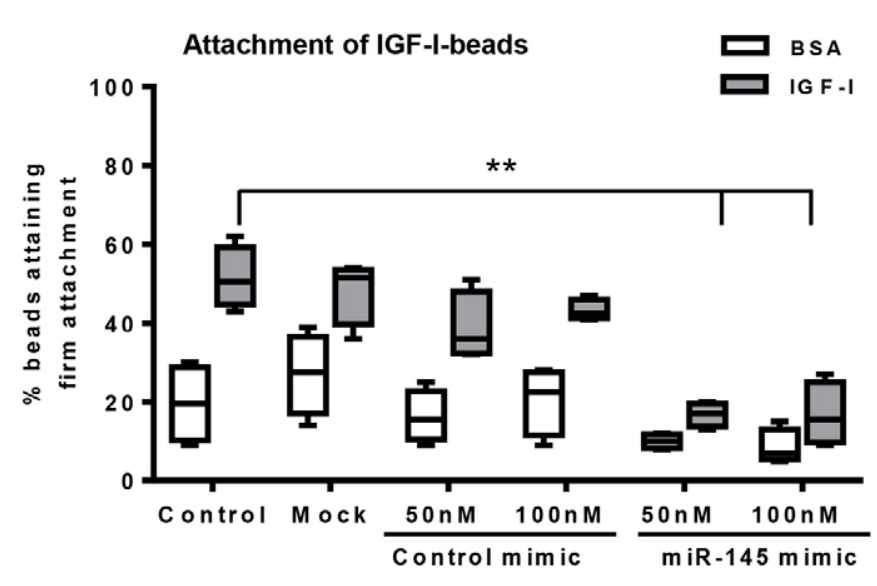

Fig. 4. miR-145 overexpression reduces IGF1-coated bead attachment. Ishikawa cells were mock-transfected, transfected with a non-targeting control miR-mimic or a miR-145 mimic (10-100 nM) and cultured for $48 \mathrm{~h}$ prior to transfer of beads coated in IGF1 (IGF-I) or BSA (negative control). Attachment was assessed after a further $48 \mathrm{~h}$ using a scale adapted from Kang et al., 2014. Data are expressed as a percentage of total beads. The box represents the 25-75th percentiles, and the median is indicated. The whiskers show the range. ${ }^{*} P<0.01(n=5$, Kruskal-Wallis test).

\section{siRNA-mediated knockdown of IGF1R suppresses embryo attachment}

The role of IGF1R in mediating embryo attachment was examined using small interfering RNA (siRNA) (100 nM) to directly reduce its expression in endometrial cells. Western blotting confirmed IGF1R expression to be reduced by $80 \%$ after $48 \mathrm{~h}$ (Fig. 5A,B). Attachment of mouse embryos (Fig. 5C,D) or IGF1-coated beads (Fig. 5E) was reduced following IGF1R knockdown $(P<0.05)$. To determine whether the effect of miR145 on attachment is mediated by its ability to target IGF1R, we prevented the interaction of miR-145 with the IGF1R 3'UTR using the specific miR-target protector for the 3804-3810 region of IGF1R mRNA (Fig. 5F,G). miR-145 mimics (50 nM) significantly reduced IGF1R protein (Fig. 5F) and attachment of IGF1-coated beads (Fig. 5G) compared to non-targeting miR mimics (control mimic). Western blotting (Fig. 5F) demonstrated that miR-145 was unable to reduce levels of IGF1R in the presence of the target site-specific target protector (IGF1R TP 3804-3810). The ability of miR-145 to reduce attachment of IGFI-loaded beads was significantly attenuated in the presence of the target-site-specific target protector (IGF1R TP 3804-3810; $100 \mathrm{nM} ; P<0.05)$ but was unaffected by the scrambled IGF1R target protector $(\Delta 3804-3810 ; 100 \mathrm{nM})($ Fig. $5 \mathrm{G})$. This suggests that the effects of miR-145 on embryo attachment are directly mediated by IGF1R.

\section{DISCUSSION}

Array approaches are cataloguing biomarkers of receptivity, comparing endometrium from different stages of the menstrual cycle or from fertile and infertile women (Altmäe et al., 2010; Ruan et al., 2013), but data are difficult to interpret in the absence of functional information on the role of putative markers in the process of implantation. Comparison of miR profiles of endometrium from RIF and normally fertile women yielded a group of candidates among which miR-145 showed an $\sim$ threefold elevation (Revel et al., 2011), leading to a hypothesis that among its targets are components vital for implantation. However, the cell populations expressing miR-145 were not identified. By using an embryo attachment model, we now demonstrate that overexpresssion of miR-145 at levels approximately comparable to those reported in RIF endometrium reduces the stability of the embryo-epithelial interaction. Given the barriers to direct examination of human embryo implantation, in vitro modelling is a viable approach to gathering relevant functional information to complement the analytical data emerging from arrays. Translated to the in vivo situation, we predict that such an effect might delay implantation to the point where corpus luteum rescue would not occur, leading to a failed pregnancy. Data from the rat similarly point to a role for miRs in regulating endometrial cell function in the implantation window (Xia et al., 2014a; Xia et al., 2014b). Such a prediction in human must be tempered by the limitations of the in vitro model, which includes the use of mouse embryos and cells from a welldifferentiated adenocarcinoma. However, a recent proteomics study of apically displayed glycoproteins in polarized Ishikawa cells showed that these were substantially similar to the epithelium in vivo (Singh and Aplin, 2014). Furthermore we have observed that hatched human blastocysts attach to these cells with kinetics that are not dissimilar to those of the mouse (unpublished).

Following previous reports that IGF1R is a target gene for miR-145 (La Rocca et al., 2009; Law et al., 2012), we have shown that overexpression of miR-145 reduces the level of IGF1R protein in endometrial epithelial cells, and identified a target site in the $3^{\prime} \mathrm{UTR}$. This is consistent with miR action in mammalian cells through translational repression (Erson and Petty, 2008). A previous study reported mRNA encoding IGF1R in the endometrial luminal epithelium during the mid-late secretory phase (Zhou et al., 1994). We have here extended these data to show the distribution of the protein through the normal cycle and, most importantly, its expression in mid secretory luminal epithelium. Direct evidence for hormonal control of IGF1R expression comes from studies in isolated human endometrial cells that report IGF1R downregulation by progesterone (Strowitzki et al., 1996). In rats, IGF1R expression in the uterus is enhanced by estrogen treatment (Ghahary and Murphy, 1989) and in baboons, expression at the glandular and luminal epithelium undergoes cyclic changes and is upregulated by estrogen (Hild-Petito et al., 1994).

Our data reveal that there might be a previously unsuspected role for IGF1R in regulating embryo attachment, with stability of adhesion to the epithelium dropping after receptor knockdown in a fashion that parallels the effect of miR-145 overexpression. IGF1R is a protein tyrosine kinase that is predominantly activated by IGF1 and IGF2. Immunoblotting identified IGF1R as being expressed in Ishikawa cells, so we adopted a ligand-coated bead assay (Kang et al., 2014) to probe its presence and function at the apical epithelial surface where embryo attachment is initiated. The observations that IGF1-coated beads can attach stably and that IGF1R knockdown impairs this process, might indicate the presence of receptor at the apical cell surface and, perhaps surprisingly, its ability to mediate an adhesive interaction with an object that approximates the size of the implanting blastocyst. By specifically inhibiting the interaction between miR-145 and IGF1R 3'UTR, without affecting interaction between miR-145 and other targets, we were further able to attribute the effects of miR-145 on embryo attachment to interaction with IGF1R. Previous work in receptive-phase mouse uterus has shown that IGF1 delivered on the surface of a bead could activate a response in the epithelium that was transduced to stroma to influence 

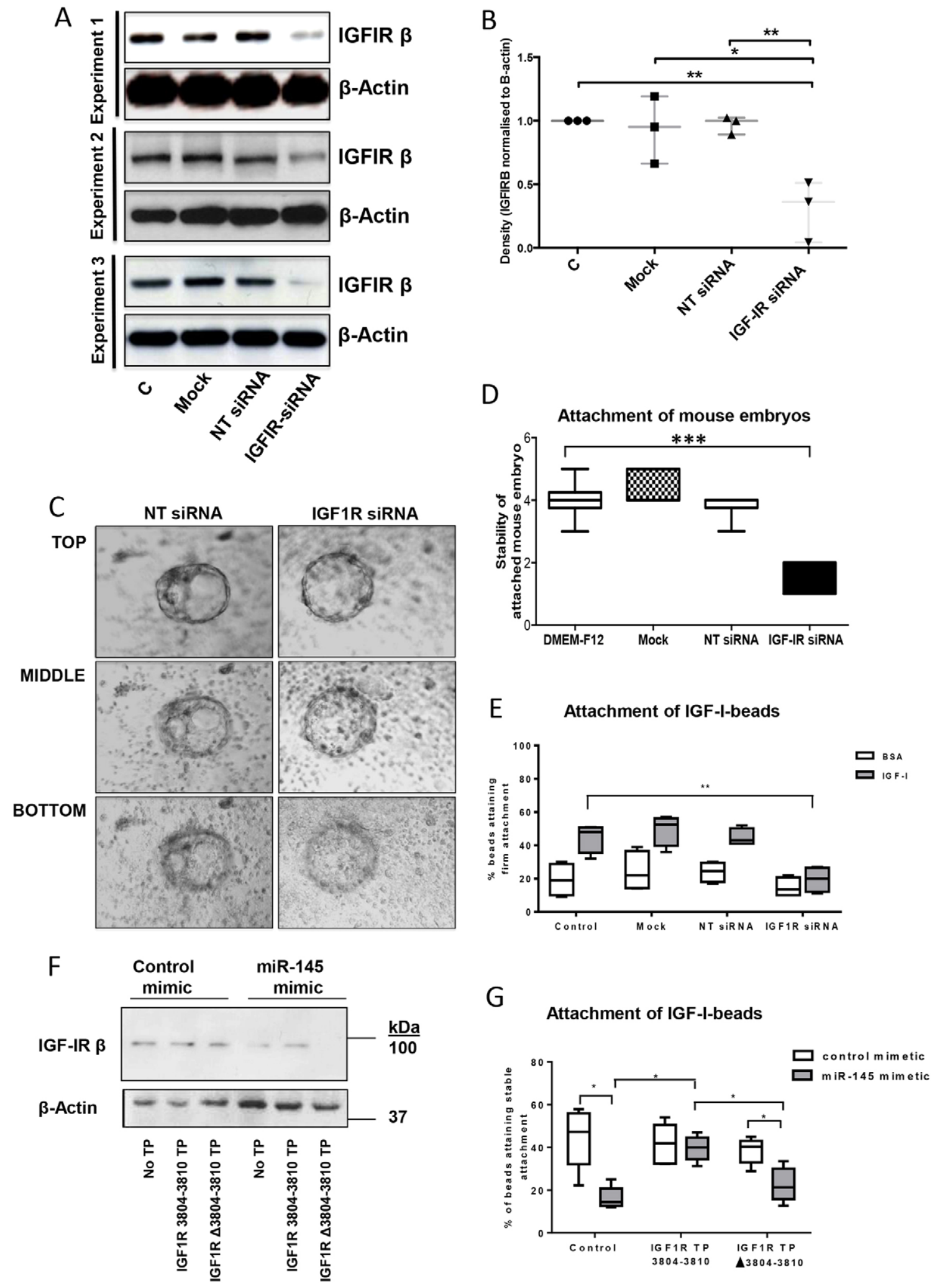

Fig. 5. See next page for legend.

vascular permeability (Paria et al., 2001). Our data further validate the ligand-coated bead interaction model as a tool to investigate expression and function of apical epithelial receptors.
Although IGF2 is expressed by both the mouse and human blastocyst (Lighten et al., 1997; Szabó and Mann, 1995), there is no evidence at present that surface-associated IGFs are displayed on trophectoderm. IGF ligands, however, are produced 
Fig. 5. The effects of miR-145 on embryo attachment are mediated by IGF1R. Non-targeting (NT) or IGF1R-specific siRNA (100 nM) were transfected into Ishikawa cells. Untreated ('C') and mock-transfected cells were included as controls. (A) Knockdown was confirmed by western blotting. Membranes were re-probed for $\beta$-actin to control for protein loading (B) Density of bands was quantified, and levels were normalized to $\beta$-actin and expressed as a fold change relative to control. ${ }^{*} P<0.05,{ }^{* *} P<0.01(n=3$, one-way ANOVA with Tukey's multiple comparison test). Data are expressed as median and interquartile range. (C-E) Cells transfected with IGF1R siRNA or appropriate controls (NT siRNA) were used for in vitro implantation using (C-D) mouse embryos or (E) ligand-coated beads [IGF1 (IGF-I) or BSA]. (C) Phase-contrast images of mouse embryos attached to Ishikawa cells after knockdown of IGF1R at three z-plane levels, taken $24 \mathrm{~h}$ after transfer of embryos $(n=15)$. (D) The stability of mouse embryo attachment to Ishikawa cells following transfection with IGF1R siRNA. ${ }^{* * *} P<0.001(n=6$, Kruskal-Wallis with Dunn's multiple comparison). (E) The effect of IGF1R knockdown on firm attachment of IGF1-coated beads was monitored. IGF1R knockdown resulted in a reduction in IGF1-coated bead attachment in comparison to controls ${ }^{* *} P<0.01$ ( $n=5$, Kruskal-Wallis test).

$(\mathrm{F}-\mathrm{G})$ Ishikawa cells were transfected with a specific miR target protector (TP) (100 nM) for the miR-145-binding site at the 3804-3810 bp region of IGF1R 3'UTR (IGF1R TP 3804-3810) or with a scrambled sequence for this region (IGF1R TP $\Delta 3804-3810$ ), which served as a negative control in the presence of a non-targeting control mimic (control mimic) or miR-145 specific miR mimic (miR-145 mimic). (F) Western blotting confirmed that the IGF1R 3'UTR IGF1R target protector (3804-3810) prevented miR-145 induced reduction in IGF1R protein expression after $48 \mathrm{~h}$. (G) Analysis of stable attachment of IGF1-coated beads was assessed after a subsequent $48 \mathrm{~h}$. BSA-coated beads were included as a control. * $P<0.05(n=5$, KruskalWallis test). For D,E,G, the box represents the 25-75th percentiles, and the median is indicated. The whiskers show the range.

endogenously in the endometrium (Giudice et al., 1993; Murphy and Ghahary, 1990). One hypothesis consistent with these data is that IGF2 released by the implanting embryo activates IGF1R locally in epithelial cells, and signals ensue through the phosphoinositide 3-kinase (PI3K) and mitogenactivated protein kinase (MAPK) pathways to influence downstream factors regulating attachment (Forbes and Westwood, 2008; Forbes et al., 2008). For example, in breast cancer cells IGF1R activation upregulates fascin-1, a modulator of adhesion and cell-cell interactions (Wong et al., 1999) to promote reorganization of cell-cell contacts (Guvakova et al., 2002a; Guvakova et al., 2002b; Yamashiro et al., 1998). Increased expression of fascin has been reported at implantation sites in mice, suggesting that it has a potential role in the initial adhesion stages (Yoon et al., 2004).

However, in recent years it has emerged that binding and crosstalk between IGF1R and cell-cell or cell-matrix adhesion molecules can occur in either the presence or absence of IGF ligand, including with integrin $\alpha v \beta 3$ (Maile et al., 2008; Xi et al., 2008), which is involved in implantation (Kang et al., 2014; Lessey, 1997). Such interactions are important for cytoskeletal organization, cell adhesion and motility (André et al., 1999; Clemmons and Maile, 2005; Juliano and Haskill, 1993; Mauro and Surmacz, 2004; Tai et al., 2003). Further work is therefore required to examine the possibility that cis interactions between growth factor receptors and adhesion molecules might occur at the apical luminal epithelial plasma membrane during implantation.

miRs alter the expression of target genes in one of two ways depending on the level of base complementarity with the 3'UTR of the target mRNA. Complete complementarity results in degradation of target, whereas partial complementarity induces translational repression (Filipowicz et al., 2008). Partial complementarity enables miRs to regulate expression of multiple targets (Erson and Petty, 2008), and despite our miR145 target blocking data demonstrating that IGF1R mediates the effects of miR-145 on embryo attachment, we cannot rule out that miR-145 has effects on implantation by targeting genes other than IGF1R. For example, miR-145 targets MUC-1 in the human embryonic kidney cell line HEK293 (Sachdeva and Mo, 2010); MUC-1 is expressed on the luminal epithelium of the endometrium (Hey et al., 1994) and is cleared at the site of implantation as a result of local juxtacrine signaling of the embryo (Singh et al., 2010). In both Ishikawa cells and primary endometrial cells, miR-145 regulates the expression of fascin (Adammek et al., 2013; Götte et al., 2010).

miR-145 is a regulator of endometrial IGF1R expression, and our in vitro model has suggested that IGF1R has a role in implantation. IGF1R is upregulated at the time of embryo attachment in vivo and reduced expression in epithelial cells destabilizes embryo attachment in vitro. Reduced IGF1R expression has been reported in mid-secretory endometrium in women with unexplained infertility (Wu and Zhou, 2004). There is evidence for regulation by leukemia inhibitory factor (LIF), which is required for endometrial receptivity in mice (Rosario et al., 2014). miR-145 in endometrium might be sensitive to steroid hormone - whereas estrogen influences expression in mouse splenic lymphocytes (Dai et al., 2008), it is under the control of progesterone in murine endometrial epithelial cells (Yuan et al., 2014). We have yet to establish whether miR-145 is under hormonal control in the human endometrium, but future studies will explore the possibility of utilizing synthetic steroids to modulate expression. We note the therapeutic potential of targeted miR-145 inhibitors (Caruso et al., 2012) and suggest that therapies to suppress miR-145 in the endometrium might improve pregnancy rates in women with RIF.

\section{MATERIALS AND METHODS \\ Endometrial tissue}

Endometrial biopsies were from pre-menopausal women at different points in the menstrual cycle were obtained anonymously from local pathology archives. Research access to the pathological archive of St Mary's Hospital was approved by Central Manchester REC. No signs of hyperplasia, neoplasia or inflammation were present in these samples. Dating of the menstrual cycle was established from histopathology reports and was confirmed by histological examination of sections stained with haematoxylin and eosin.

\section{Cell culture}

Ishikawa cells (a well-differentiated human endometrial adenocarcinoma line), obtained from American Type Cell Culture (ATCC), were maintained in phenol red-free DMEM/F12 medium (Invitrogen, UK) supplemented with $10 \%$ fetal bovine serum, $100 \mathrm{U} / \mathrm{ml}$ penicillin, $100 \mu \mathrm{g} /$ $\mathrm{ml}$ streptomycin and $2 \mathrm{mM} \mathrm{L}$-glutamine. Cells were grown in $95 \%$ air and $5 \% \mathrm{CO}_{2}$ on matrigel (1:8 dilution; growth factor-reduced, $\mathrm{BD}, \mathrm{UK}$ ) for further attachment assays.

\section{Animals, superovulation and embryo recovery}

All experiments were conducted under a Home Office license and the Animal Act, 1986, and had local ethical approval for care and use of laboratory animals. C57BL/6 strain mice were maintained by the Biomedical Services Unit at the University of Manchester. Mice were kept under standard environmental conditions of $12 \mathrm{~h}$ light and $12 \mathrm{~h}$ dark and housed at $20-22^{\circ} \mathrm{C}$ and $40-60 \%$ humidity with food and water provided at ad libitum and males (less than 6 months old) were caged singly. Female mice (6-8 weeks) were superovulated with 5 IU of pregnant mare serum gonadotrophin (PMSG, Calbiochem, Nottingham, UK) and ovulation was synchronized by 5 IU human chorionic gonadotrophin (hCG, Intervert UK, Milton Keynes, UK) 46-48 h later, both by intraperitoneal injection. Females were placed singly with males 
of the same strain overnight. The presence of a vaginal plug the following morning (day 1 of pregnancy) was used as an indicator of successful mating. Pregnant mice were killed on day 2, $48 \mathrm{~h}$ after hCG injection. Using sterilized scissors and forceps the lower abdominal cavity was incised and both oviducts dissected. Two-cell embryos were obtained from the oviduct either by flushing using a $34 \mathrm{G}$ blunt-ended stainless steel needle (Cooper Needleworks, Birmingham, UK) and syringe. Flushed embryos were washed with M2 media (Sigma) supplemented with $4 \mathrm{mg} / \mathrm{ml}$ BSA washed in KSOM (Millipore, UK) and cultured in a $30 \mu \mathrm{l}$ drop of $\mathrm{KSOM}$ covered with mineral oil at $5 \% \mathrm{CO}_{2}, 37^{\circ} \mathrm{C}$ until the blastocyst stage. Only expanded blastocysts with clearly observable inner cell mass and trophectoderm on day 5 were included in the study.

\section{IGF1R localization}

Sections of endometrial tissue ( $5 \mu \mathrm{m}$ thick), or Ishikawa cells fixed in $4 \%$ PFA were incubated overnight at $4{ }^{\circ} \mathrm{C}$ in a humidity chamber, with either rabbit polyclonal anti-IGF1R antibody (1:75; Cell Signaling Technologies, 3027) or IgG purified from rabbit serum (1:2000; Cell Signaling Technologies) followed by anti-rabbit biotinylated antibody (1:200) (Dako), avidin peroxidase and then developed by DAB as previously described (Forbes et al., 2008).

\section{Overexpression of hsa-miR-145 in Ishikawa cells}

Non-targeting (Cy3-labeled Pre-miR precursor negative control) or miR145 specific miR mimics (Pre-miR mimics; Ambion, UK) were transfected into Ishikawa cells $(10-100 \mathrm{nM})$ with DharmaFECT2 reagent (Dharmacon, UK) as previously described (Kang et al., 2014). Following transfection, cells were cultured for up to $96 \mathrm{~h}$ in $20 \% \mathrm{O}_{2}$ at $37^{\circ} \mathrm{C}$. Prior to analysis in subsequent experiments, overexpression was confirmed by QPCR. The effect of miR-145 overexpression was compared with that of three controls: untreated cells, tissue exposed to transfection procedure alone (mock) or tissue transfected with nontargeting miR mimic (Pre-miR precursor negative control, Ambion, UK) which has no known homology to any mammalian miRs.

\section{SiRNA mediated knockdown of IGF1R}

siRNA sequences used to target the human IGF1R gene (GenBank NM000875) were either in a SMARTPool containing four different target sequences: A, 5'-GGAAGCACCCUUUAAGAAU-3'; B, 5'-GGACUCAGUACGCCGUUUA-3'; C, 5' -AAAUACGGAUCACAAGUUG-3' and D, 5'-AGUGAGAUCUUGUACAUUC-3' (100-500 nM; Dharmacon, UK), or using a single validated sequence 5'-GGAAUACAGGAAGUAUGGA-3' (100-500 nM; Ambion, UK). Silencer Select Negative Control siRNA (Ambion, UK), which does not target any known sequence in the human genome, was used in control experiments. The specific and non-targeting siRNA sequences were transfected into Ishikawa cells using DharmaFECT 2 reagent as previously described (Kang et al., 2014).

\section{Quantitative RT-PCR based analysis of $\mathbf{m i R}$ expression}

Total RNA was extracted from Ishikawa cells from at least six separate experiments by using the miRVANA total RNA extraction kit (Ambion, UK) and quantified using a Quant-iT Ribogreen kit (Molecular Probes). The expression of miRs was assessed using the miRCURY LNA ${ }^{\mathrm{TM}}$ Universal RT microRNA PCR system (Exiqon) following the manufacturer's instructions. Briefly, $25 \mathrm{ng}$ RNA was reversed transcribed using Universal cDNA Synthesis kit (Exiqon), which allows polyadenylation and reverse transcription of all miRs within the sample into cDNA in a single reaction step. Individual miRs were then detected using LNA-enhanced miRNA-specific primer sets (Exiqon) for hsa-miR-145 (target sequence: 5'-GUCCAGUUUUCCCAGGAAUCCCU-3') or 5S rRNA. miR expression was quantified against standard curves generated from human reference total RNA (Stratagene, USA). PCRs were performed in duplicate for each sample to control for user error, using a Stratagene MX3000P real-time PCR machine. Values were only deemed acceptable when each replicate sample deviated by less than 1 from its matched duplicate. The CT value for each sample (i.e. the average of the two duplicates) was used to calculate absolute values (determined from the standard curve). To further control for variations in sample input into the PCR assay, levels of miR-145 were normalized to 5S rRNA, which is present at equal levels in all our samples (data not shown). Data were then expressed as fold change compared to control and analysed using the Wilcoxon signed-rank test.

\section{Quantitative RT-PCR based analysis of mRNA expression}

Total RNA was extracted from Ishikawa cells by using the miRVANA total RNA extraction kit (Ambion UK) and quantified using a Quant-iT Ribogreen kit (Molecular Probes). $100 \mathrm{ng}$ of total RNA from each sample was reverse transcribed using AffinityScript cDNA synthesis kit (Stratagene, USA) and IGF1R and $\beta$-actin mRNA was amplified by QPCR using $200 \mathrm{nM}$ primers $55^{\circ} \mathrm{C}$ [IGF1R: forward, 5'GAAGGAGGAGGCTGAATAC-3'; reverse, 5'- CTACAACATCACCGACC-3'; Invitrogen (Paisley, UK); $\beta$-actin: forward, 5'AGCCACCCCACTTCTCTCTAA-3', reverse, 5'-ACACGAAAGCAATGCTATCACCT-3' (MWG Biotech, UK)] and Stratagene Brilliant SYBR Green II QPCR mastermix, with 5-carboxy-x-rhodamine as a passive reference dye in a Stratagene's MX3000P real time PCR machine. mRNA expression was quantified against standard curves generated from human reference total RNA (Stratagene, USA). Data were normalized to $\beta$-actin mRNA then expressed as a percentage of levels measured in cells transfected with pre-miR negative control mimic, and analysed using the Wilcoxon signed-rank test.

\section{In vitro implantation models \\ Embryo attachment assay}

Mouse embryos (5 days old) were transferred onto Ishikawa cells in independent microwells of a 96-well plate. Multiple observations of attaching embryos from $24-48 \mathrm{~h}$ after transfer allowed distinct stages of attachment to be identified. A standardized plate movement protocol was implemented to characterize the stability of attachment: the plate was moved quickly three times laterally and then orthogonally to detect unattached embryos. Upon moving the plate, unattached embryos floated, or rolled, over the epithelial surface. Attached embryos were then examined for tandem movement when the microscope stage was tapped. At initial attachment, embryo wobble was observed, whereas at more advanced stages of attachment, embryos moved fully in concert with the underlying epithelial layer. Five stages of attachment were defined and used as a measurement scale as previously described (Carver et al., 2003; Kang et al., 2014).

\section{Bead attachment assay}

$10 \mu 1$ of embryo-sized beads (Bio-Rad) were washed six times in sterile PBS. Beads were then incubated with $20 \mu 1$ of $100 \mathrm{ng} / \mu 1 \mathrm{IGF} 1$ (R\&D) and BSA (RIA Grade, Cat no: A7888, Sigma) dissolved in PBS, and overlaid with $1 \mathrm{ml}$ of mineral oil (Sigma) at $37^{\circ} \mathrm{C}$ for $2 \mathrm{~h}$. Beads were used immediately after incubation. Prior to co-culture, the mineral oil was removed and the beads were washed in sterile PBS to remove any unbound growth factor. Beads were then re-suspended in sterile PBS and 10-15 beads bearing IGF1 or BSA were transferred onto each well of Ishikawa cells in 96-well plate as previously described (Kang et al., 2014). After 24-48 h of co-culture, cells containing beads were washed with PBS and fixed with $4 \%$ PFA. The number of attached beads was counted and analysed by normalizing to the total number of beads transferred.

\section{Western blotting}

Following appropriate experimental treatment, cells were washed in PBS and scraped into RIPA buffer. $30 \mu \mathrm{g}$ of protein was loaded into each well of $8 \%$ SDS-polyacrylamide gels and protein was separated electrophoretically by molecular mass. The separated proteins were then transferred onto PVDF membrane (Millipore) and blocked with 5\% BSA in TBS with Tween-20 at room temperature for $1.5 \mathrm{~h}$. Membranes were then probed with rabbit anti-phospho-IGF1R antibody (1:1000; Product number 3027; Cell Signaling Technologies), or a rabbit antibody against the $\beta$ subunit of IGF1R (C20;2 $\mu \mathrm{g} / \mathrm{ml}$; Santa Cruz Biotech) at $4^{\circ} \mathrm{C}$ overnight, washed with TBS with Tween-20, and incubated with horseradish peroxidase (HRP)-conjugated anti-rabbit-IgG antibody at room temperature for $1 \mathrm{~h}$. The protein was exposed to the enhanced 
chemiluminescence system (Amersham) and then to Amersham or Kodak hyperfilm. Blots were stripped and reprobed with mouse-anti- $\beta$-actin $(4.5 \mu \mathrm{g} / \mathrm{ml}$; Sigma) or rabbit anti-GAPDH (1:1000; Cell Signaling Technologies) antibodies to control for protein loading. ImageJ (National Institute of Health, Bethesda, MD) was used to quantify bands comparing to loading control.

\section{Assessment of miR-145-IGF1R interaction}

pmiR-GLO Dual-Luciferase miRNA Target Expression Vector (Promega) was used to demonstrate the interaction between miR-145 and IGF1R. The $3^{\prime}$ untranslated region (UTR) of IGF1R was cloned into the multiple cloning site (MCS) in the 3'UTR of the firefly luciferase gene. The principle of the vector is such that if endogenous miRs bind to the $3^{\prime}$ UTR following introduction into cells, translation of firefly luciferase will be reduced.

\section{IGF1R 3'UTR luciferase reporter constructs}

Two 42 base pair (bp) oligonucleotides and complementary antisense strands were designed using TargetScan (http://www.targetscan.org) to correspond to the highly conserved region of the IGF1R $3^{\prime}$ UTR to which miR-145 is predicted to bind (3804-3810 bp; supplementary material Table S1). Pme1 and Xba1 overhangs were incorporated to ensure correct orientation of the oligonucleotide from $5^{\prime}$ to $3^{\prime}$. A Not1 restriction site was included, to act as an internal restriction site to confirm successful ligation. A scrambled version of the first predicted binding site was included as a control (supplementary material Table S1).

Prior to ligation, the pmiR-GLO Dual-Luciferase miRNA Target Expression vector was linearized with Pme1 (New England Bio Labs) and Xba1 (Roche) restriction enzymes to ensure complementarity with oligonucleotide overhangs. $1 \mu \mathrm{g}$ of vector was incubated with $1 \mu \mathrm{l}$ of each restriction enzyme and $2 \mu \mathrm{l}$ of $10 \times$ CutSmart Buffer 4 (New England Bio Labs) overnight at $37^{\circ} \mathrm{C}$, samples were then heated to $65^{\circ} \mathrm{C}$ for $15 \mathrm{~min}$ to deactivate enzymes prior to electrophoresis. The linearized vector underwent gel electrophoresis on a $1 \%$ agarose gel and was then extracted using the Qiagen gel extraction and purification kit. Prior to ligation with the linearized vector, complementary oligonucleotides were annealed using Oligo Annealing Buffer (Promega) following the manufacturer's instructions. $4 \mathrm{ng}$ of annealed oligonucleotides were incubated with $50 \mathrm{ng}$ of linearized vector, $2 \mu \mathrm{l}$ of T4 DNA ligase (New England BioLabs) and $1 \mu 1$ of $10 \times$ T4 DNA ligase buffer (New England BioLabs) at $4{ }^{\circ} \mathrm{C}$ overnight. Following ligation the vector, which contains an ampicillin resistance gene, was transformed into XL-10 Gold Ultra competent cells (Aligent Technologies) using heat shock as per the manufacturer's instructions. Cells were then plated onto ampicillincontaining agar plates and incubated at $37^{\circ} \mathrm{C}$ overnight. Colonies were selected and grown overnight in LB medium containing ampicillin at $37^{\circ} \mathrm{C}$ and the vector was purified using the Qiagen mini prep kit (Thermoscientific). Not1 digestion was performed to confirm successful ligation of the IGF1R and scrambled 3'UTR binding sites.

\section{Luciferase reporter assay}

Following successful ligation, vectors (50 ng) containing miR-145, or IGF1R 3'UTR sites and pSV- $\beta$-Galactosidase Control Vector (100 ng; Promega) were transfected into Ishikawa cells alone or in combination with miR-145 or non-targeting miR mimics $(100 \mathrm{nM})$ using DharmaFECT2 as described above. Untreated and mock-transfected samples and the pmiRGLO vector were included as controls. $24 \mathrm{~h}$ after transfection cells were washed twice in PBS and lysed with passive lysis buffer (Promega). Levels of Firefly luciferase were read using the Orion L Microplate Luminometer (Titertek) using the luciferase reporter assay (Promega) according to the manufacturer's instructions. Levels of $\beta$-galactosidase were measured using the mammalian $\beta$-galactosidase assay kit (Pierce, Thermoscientific). Firefly luciferase was normalized to $\beta$-galactosidase in each sample to control for transfection efficiency.

\section{miR-binding site target protector}

Target protectors (purchased from Qiagen) were designed to correspond to the region of the IGF1R $3^{\prime}$ UTR (3804-3810 bp) to which miR-145 is predicted to bind (5'-TACCTACCGGTTTCCACAACTGGATTTCTACAGATCATTC- ${ }^{\prime}$, where the underlined region represents the seed sequence). BLAST analysis demonstrated that the target protector did not have any homology to any mammalian genes, other than IGF1R. The target protector is therefore specific and allows effective blocking of miR-145-IGF1R interaction without influencing binding of miR-145 to its other targets (Stanton and Giraldez, 2011). Effects of miR-145 altered in the presence of the target protector, are thus attributable to interaction between miR-145 and IGF1R. A scrambled target protector was designed as a control (sequence, 5'-TACCTACCGGTTTCCACAAAAGGATTTCTACAGATCATTC-3', $\Delta 3804-3810$ bp). Ishikawa cells were transfected with scrambled or IGF1R target protectors $(100 \mathrm{nM})$ individually or in combination with miR-145 or non-targeting mimics $(50 \mathrm{nM}) .48 \mathrm{~h}$ later, IGF1 or BSA-coated beads were added to the cells and $24-48 \mathrm{~h}$ later the ability of miR-145 to influence IGF1R expression and bead attachment were assessed.

\section{Competing interests}

The authors declare no competing or financial interests.

\section{Author contributions}

K.F. and Y.J.K. conceived the idea and designed the experiments. J.D.A. and Y.J.K. developed the bead attachment model. M.L., K.F. and L.C.M. designed and prepared all 3'UTR luciferase reporter constructs. Y.J.K., M.L., L.C.M. and K.F. performed the experiments. All authors contributed to data interpretation. K.F. and J.D.A. supervised the project. Y.J.K., K.F., M.L. and J.D.A. wrote the manuscript with input from L.C.M. and S.J.K.

\section{Funding}

K.F. and L.C.M. were supported by University of Manchester Stepping Stone Fellowships. K.F. was the recipient of a Society for Endocrinology Early Career Grant. The Maternal and Fetal Health Research Centre is supported by funding from Tommy's the Baby Charity; an Action Research Endowment Fund; the Manchester Biomedical Research Centre; and the Greater Manchester Comprehensive Local Research Network.

\section{Supplementary material}

Supplementary material available online at

http://jcs.biologists.org/lookup/suppl/doi:10.1242/jcs.164004/-/DC1

\section{References}

Achache, H. and Revel, A. (2006). Endometrial receptivity markers, the journey to successful embryo implantation. Hum. Reprod. Update 12, 731-746.

Adammek, M., Greve, B., Kassens, N., Schneider, C., Bruggemann, K., Schuring, A. N., Starzinski-Powitz, A., Kiesel, L. and Gotte, M. (2013). MicroRNA miR-145 inhibits proliferation, invasiveness, and stem cell phenotype of an in vitro endometriosis model by targeting multiple cytoskeletal elements and pluripotency factors. Fertil. Steril. 99, 1346-1355, e5.

Altmäe, S., Martínez-Conejero, J. A., Salumets, A., Simón, C., Horcajadas, J. A. and Stavreus-Evers, A. (2010). Endometrial gene expression analysis at the time of embryo implantation in women with unexplained infertility. Mol. Hum. Reprod. 16, 178-187.

Altmäe, S., Esteban, F. J., Stavreus-Evers, A., Simón, C., Giudice, L., Lessey, B. A., Horcajadas, J. A., Macklon, N. S., D'Hooghe, T., Campoy, C. et al. (2014). Guidelines for the design, analysis and interpretation of 'omics' data: focus on human endometrium. Hum. Reprod. Update 20, 12-28.

André, F., Rigot, V., Thimonier, J., Montixi, C., Parat, F., Pommier, G., Marvaldi, J. and Luis, J. (1999). Integrins and E-cadherin cooperate with IGF-I to induce migration of epithelial colonic cells. Int. J. Cancer 83, 497-505.

Aplin, J. D. (2000). The cell biological basis of human implantation. Baillieres Best Pract. Res. Clin. Obstet. Gynaecol. 14, 757-764.

Aplin, J. D. (2007). Embryo implantation: the molecular mechanism remains elusive. Reprod. Biomed. Online 14, 49-55.

Aplin, J. D. and Kimber, S. J. (2004). Trophoblast-uterine interactions at implantation. Reprod. Biol. Endocrinol. 2, 48.

Aplin, J. D. and Singh, H. (2008). Bioinformatics and transcriptomics studies of early implantation. Ann. N. Y. Acad. Sci. 1127, 116-120.

Bartel, D. P. (2004). MicroRNAs: genomics, biogenesis, mechanism, and function. Cell 116, 281-297.

Bazer, F. W., Spencer, T. E., Johnson, G. A., Burghardt, R. C. and Wu, G. (2009). Comparative aspects of implantation. Reproduction 138, 195-209.

Bergh, P. A. and Navot, D. (1992). The impact of embryonic development and endometrial maturity on the timing of implantation. Fertil. Steril. 58, 537-542.

Burney, R. O., Talbi, S., Hamilton, A. E., Vo, K. C., Nyegaard, M., Nezhat, C. R., Lessey, B. A. and Giudice, L. C. (2007). Gene expression analysis of endometrium reveals progesterone resistance and candidate susceptibility genes in women with endometriosis. Endocrinology 148, 3814-3826. 
Burney, R. O., Hamilton, A. E., Aghajanova, L., Vo, K. C., Nezhat, C. N. Lessey, B. A. and Giudice, L. C. (2009). MicroRNA expression profiling of eutopic secretory endometrium in women with versus without endometriosis. Mol. Hum. Reprod. 15, 625-631.

Cakmak, H. and Taylor, H. S. (2011). Implantation failure: molecular mechanisms and clinical treatment. Hum. Reprod. Update 17, 242-253.

Caruso, P., Dempsie, Y., Stevens, H. C., McDonald, R. A., Long, L., Lu, R., White, K., Mair, K. M., McClure, J. D., Southwood, M. et al. (2012). A role for miR-145 in pulmonary arterial hypertension: evidence from mouse models and patient samples. Circ. Res. 111, 290-300.

Carver, J., Martin, K., Spyropoulou, I., Barlow, D., Sargent, I. and Mardon, H. (2003). An in-vitro model for stromal invasion during implantation of the human blastocyst. Hum. Reprod. 18, 283-290.

Cha, J., Sun, X. and Dey, S. K. (2012). Mechanisms of implantation: strategies for successful pregnancy. Nat. Med. 18, 1754-1767.

Clemmons, D. R. and Maile, L. A. (2005). Interaction between insulin-like growth factor-I receptor and alphaVbeta3 integrin linked signaling pathways: cellular responses to changes in multiple signaling inputs. Mol. Endocrinol. 19, 1-11.

Coughlan, C., Ledger, W., Wang, Q., Liu, F., Demirol, A., Gurgan, T., Cutting, R., Ong, K., Sallam, H. and Li, T. C. (2014). Recurrent implantation failure: definition and management. Reprod. Biomed. Online 28, 14-38.

Dai, R., Phillips, R. A., Zhang, Y., Khan, D., Crasta, O. and Ahmed, S. A. (2008). Suppression of LPS-induced Interferon-gamma and nitric oxide in splenic lymphocytes by select estrogen-regulated microRNAs: a novel mechanism of immune modulation. Blood 112, 4591-4597.

de los Santos, M. J., Mercader, A., Galan, A., Albert, C., Romero, J. L. and Pellicer, A. (2003). Implantation rates after two, three, or five days of embryo culture. Placenta 24 Suppl. B, S13-S19.

de Mouzon, J., Goossens, V., Bhattacharya, S., Castilla, J. A., Ferraretti, A. P. Korsak, V., Kupka, M., Nygren, K. G., Nyboe Andersen, A.; European IVFmonitoring (EIM) Consortium, for the European Society of Human Reproduction and Embryology (ESHRE) (2010). Assisted reproductive technology in Europe, 2006: results generated from European registers by ESHRE. Hum. Reprod. 25, 1851-1862.

Dey, S. K. (2004). Focus on implantation. Reproduction 128, 655-656.

Domínguez, F., Garrido-Gómez, T., López, J. A., Camafeita, E., Quiñonero, A., Pellicer, A. and Simón, C. (2009). Proteomic analysis of the human receptive versus non-receptive endometrium using differential in-gel electrophoresis and MALDI-MS unveils stathmin 1 and annexin A2 as differentially regulated. Hum. Reprod. 24, 2607-2617.

Enders, A. C. (1989). Morphological manifestations of maturation of the blastocyst. Prog. Clin. Biol. Res. 294, 211-223.

Erson, A. E. and Petty, E. M. (2008). MicroRNAs in development and disease. Clin. Genet. 74, 296-306.

Farrokhnia, F., Aplin, J. D., Westwood, M. and Forbes, K. (2014). MicroRNA regulation of mitogenic signaling networks in the human placenta. J. Biol. Chem. 289, 30404-30416.

Ferraretti, A. P., Goossens, V., de Mouzon, J., Bhattacharya, S., Castilla, J. A., Korsak, V., Kupka, M., Nygren, K. G., Nyboe Andersen, A.; European IVFmonitoring (EIM); Consortium for European Society of Human Reproduction and Embryology (ESHRE) (2012). Assisted reproductive technology in Europe, 2008: results generated from European registers by ESHRE. Hum. Reprod. 27, 2571-2584.

Filipowicz, W., Bhattacharyya, S. N. and Sonenberg, N. (2008). Mechanisms of post-transcriptional regulation by microRNAs: are the answers in sight? Nat. Rev. Genet. 9, 102-114.

Forbes, K. and Westwood, M. (2008). The IGF axis and placental function. a mini review. Horm. Res. 69, 129-137.

Forbes, K., Westwood, M., Baker, P. N. and Aplin, J. D. (2008). Insulin-like growth factor I and II regulate the life cycle of trophoblast in the developing human placenta. Am. J. Physiol. 294, C1313-C1322.

Forbes, K., Farrokhnia, F., Aplin, J. D. and Westwood, M. (2012). Dicerdependent miRNAs provide an endogenous restraint on cytotrophoblast proliferation. Placenta 33, 581-585.

Garrido-Gomez, T., Dominguez, F. and Simon, C. (2010). Proteomics of embryonic implantation. Handb Exp. Pharmacol, 2010, 67-78.

Ghahary, A. and Murphy, L. J. (1989). Uterine insulin-like growth factor-I receptors: regulation by estrogen and variation throughout the estrous cycle. Endocrinology 125, 597-604.

Giudice, L. C., Dsupin, B. A., Jin, I. H., Vu, T. H. and Hoffman, A. R. (1993) Differential expression of messenger ribonucleic acids encoding insulin-like growth factors and their receptors in human uterine endometrium and decidua. J. Clin. Endocrinol. Metab. 76, 1115-1122.

Götte, M., Mohr, C., Koo, C. Y., Stock, C., Vaske, A. K., Viola, M., Ibrahim, S. A., Peddibhotla, S., Teng, Y. H., Low, J. Y. et al. (2010). miR-145-dependent targeting of junctional adhesion molecule $\mathrm{A}$ and modulation of fascin expression are associated with reduced breast cancer cell motility and invasiveness. Oncogene 29, 6569-6580.

Guvakova, M. A., Adams, J. C. and Boettiger, D. (2002a). Functional role of alpha-actinin, PI 3-kinase and MEK1/2 in insulin-like growth factor I receptor kinase regulated motility of human breast carcinoma cells. J. Cell Sci. 115, 4149-4165.

Guvakova, M. A., Boettiger, D. and Adams, J. C. (2002b). Induction of fascin spikes in breast cancer cells by activation of the insulin-like growth factor-I receptor. Int. J. Biochem. Cell Biol. 34, 685-698.
Hey, N. A., Graham, R. A., Seif, M. W. and Aplin, J. D. (1994). The polymorphic epithelial mucin MUC1 in human endometrium is regulated with maximal expression in the implantation phase. J. Clin. Endocrinol. Metab. 78, 337-342.

Hild-Petito, S., Verhage, H. G. and Fazleabas, A. T. (1994). Characterization, localization, and regulation of receptors for insulin-like growth factor I in the baboon uterus during the cycle and pregnancy. Biol. Reprod. 50, 791-801.

Juliano, R. L. and Haskill, S. (1993). Signal transduction from the extracellular matrix. J. Cell Biol. 120, 577-585.

Kane, M. T., Morgan, P. M. and Coonan, C. (1997). Peptide growth factors and preimplantation development. Hum. Reprod. Update 3, 137-157.

Kang, Y. J., Forbes, K., Carver, J. and Aplin, J. D. (2014). The role of the osteopontin-integrin $\alpha \mathrm{v} \beta 3$ interaction at implantation: functional analysis using three different in vitro models. Hum. Reprod. 29, 739-749.

Koot, Y. E., Boomsma, C. M., Eijkemans, M. J., Lentjes, E. G. and Macklon, N. S. (2011). Recurrent pre-clinical pregnancy loss is unlikely to be a 'cause' of unexplained infertility. Hum. Reprod. 26, 2636-2641.

Kuokkanen, S., Chen, B., Ojalvo, L., Benard, L., Santoro, N. and Pollard, J. W. (2010). Genomic profiling of microRNAs and messenger RNAs reveals hormonal regulation in microRNA expression in human endometrium. Biol. Reprod. 82, 791-801.

La Rocca, G., Badin, M., Shi, B., Xu, S. Q., Deangelis, T., Sepp-Lorenzinoi, L. and Baserga, R. (2009). Mechanism of growth inhibition by MicroRNA 145: the role of the IGF-I receptor signaling pathway. J. Cell. Physiol. 220, 485-491.

Law, P. T., Ching, A. K., Chan, A. W., Wong, Q. W., Wong, C. K., To, K. F. and Wong, N. (2012). MiR-145 modulates multiple components of the insulin-like growth factor pathway in hepatocellular carcinoma. Carcinogenesis 33, 11341141.

Lessey, B. A. (1997). Integrins and the endometrium: new markers of uterine receptivity. Ann. N. Y. Acad. Sci. 828, 111-122.

Lighten, A. D., Hardy, K., Winston, R. M. and Moore, G. E. (1997). Expression of mRNA for the insulin-like growth factors and their receptors in human preimplantation embryos. Mol. Reprod. Dev. 47, 134-139.

Maile, L. A., Aday, A. W., Busby, W. H., Sanghani, R., Veluvolu, U. and Clemmons, D. R. (2008). Modulation of integrin antagonist signaling by ligand binding of the heparin-binding domain of vitronectin to the alphaVbeta3 integrin. J. Cell. Biochem. 105, 437-446.

Margalioth, E. J., Ben-Chetrit, A., Gal, M. and Eldar-Geva, T. (2006). Investigation and treatment of repeated implantation failure following IVF-ET. Hum. Reprod. 21, 3036-3043.

Mauro, L. and Surmacz, E. (2004). IGF-I receptor, cell-cell adhesion, tumour development and progression. J. Mol. Histol. 35, 247-253.

Murphy, L. J. and Ghahary, A. (1990). Uterine insulin-like growth factor-1: regulation of expression and its role in estrogen-induced uterine proliferation. Endocr. Rev. 11, 443-453.

Nimbkar-Joshi, S., Rosario, G., Katkam, R. R., Manjramkar, D. D., Metkari, S. M., Puri, C. P. and Sachdeva, G. (2009). Embryo-induced alterations in the molecular phenotype of primate endometrium. J. Reprod. Immunol. 83, 65-71.

Paria, B. C., Ma, W., Tan, J., Raja, S., Das, S. K., Dey, S. K. and Hogan, B. L. (2001). Cellular and molecular responses of the uterus to embryo implantation can be elicited by locally applied growth factors. Proc. Natl. Acad. Sci. USA 98 , 1047-1052.

Polanski, L. T., Barbosa, M. A., Martins, W. P., Baumgarten, M. N., Campbell, B., Brosens, J., Quenby, S. and Raine-Fenning, N. (2014). Interventions to improve reproductive outcomes in women with elevated natural killer cells undergoing assisted reproduction techniques: a systematic review of literature. Hum. Reprod. 29, 65-75.

Psychoyos, A. (1974). Hormonal control of ovoimplantation. Vitam. Horm. 31, 201-256.

Rai, P., Kota, V., Sundaram, C. S., Deendayal, M. and Shivaji, S. (2010). Proteome of human endometrium: Identification of differentially expressed proteins in proliferative and secretory phase endometrium. Proteomics Clin. Appl. 4, 48-59.

Rashid, N. A., Lalitkumar, S., Lalitkumar, P. G. and Gemzell-Danielsson, K. (2011). Endometrial receptivity and human embryo implantation. Am. J. Reprod. Immunol. 66 Suppl. 1:, 23-30.

Revel, A., Achache, H., Stevens, J., Smith, Y. and Reich, R. (2011). MicroRNAs are associated with human embryo implantation defects. Hum. Reprod. 26, 2830-2840.

Rosario, G. X., Hondo, E., Jeong, J. W., Mutalif, R., Ye, X., Yee, L. X. and Stewart, C. L. (2014). The LIF-mediated molecular signature regulating murine embryo implantation. Biol. Reprod. 91, 66.

Ruan, Y., Qian, W. P., Zhang, C. H., Zhou, L. and Hou, Z. H. (2013). [Study on microRNA expression in endometrium of luteal phase and its relationship with infertility of endometriosis]. Zhonghua Fu Chan Ke Za Zhi 48, 907-910.

Sachdeva, M. and Mo, Y. Y. (2010). MicroRNA-145 suppresses cell invasion and metastasis by directly targeting mucin 1. Cancer Res. 70, 378-387.

Salker, M. S., Christian, M., Steel, J. H., Nautiyal, J., Lavery, S., Trew, G., Webster, Z., Al-Sabbagh, M., Puchchakayala, G., Föller, M. et al. (2011). Deregulation of the serum- and glucocorticoid-inducible kinase SGK1 in the endometrium causes reproductive failure. Nat. Med. 17, 1509-1513.

Simón, C., Martin, J. C., Meseguer, M., Caballero-Campo, P., Valbuena, D. and Pellicer, A. (2000a). Embryonic regulation of endometrial molecules in human implantation. J. Reprod. Fertil. Suppl. 55, 43-53.

Simón, C., Martín, J. C. and Pellicer, A. (2000b). Paracrine regulators of implantation. Baillieres Best Pract. Res. Clin. Obstet. Gynaecol. 14, 815-826. 
Singh, H. and Aplin, J. D. (2015). Endometrial apical glycoproteomic analysis reveals roles for cadherin 6 , desmoglein-2 and plexin b2 in epithelial integrity. Mol. Hum. Reprod. 21, 81-94.

Singh, H., Nardo, L., Kimber, S. J. and Aplin, J. D. (2010). Early stages of implantation as revealed by an in vitro model. Reproduction 139, 905-914.

Staton, A. A., Giraldez, A. J. (2011). Use of target protector morpholinos to analyze the physiological roles of specific miRNA-mRNA pairs in vivo. Nat Protoc. 6, 2035-2049.

Strowitzki, T., Singer, G. A., Rettig, I. and Capp, E. (1996). Characterization of receptors for insulin-like growth factor type I on cultured human endometrial stromal cells: downregulation by progesterone. Gynecol. Endocrinol. 10, 229-240.

Szabó, P. E. and Mann, J. R. (1995). Allele-specific expression and total expression levels of imprinted genes during early mouse development: implications for imprinting mechanisms. Genes Dev. 9, 3097-3108.

Tabibzadeh, S. S., Mortillo, S. and Gerber, M. A. (1987). Immunoultrastructura localization of la antigens in human endometrium. Arch. Pathol. Lab. Med. 111 32-37.

Tai, Y. T., Podar, K., Catley, L., Tseng, Y. H., Akiyama, M., Shringarpure, R. Burger, R., Hideshima, T., Chauhan, D., Mitsiades, N. et al. (2003). Insulinlike growth factor-1 induces adhesion and migration in human multiple myeloma cells via activation of beta1-integrin and phosphatidylinositol $3^{\prime}$-kinase/AKT signaling. Cancer Res. 63, 5850-5858.

Vilella, F., Ramirez, L. B. and Simón, C. (2013). Lipidomics as an emerging tool to predict endometrial receptivity. Fertil. Steril. 99, 1100-1106.

Wong, V., Ching, D., McCrea, P. D. and Firestone, G. L. (1999). Glucocorticoid down-regulation of fascin protein expression is required for the steroid-induced formation of tight junctions and cell-cell interactions in rat mammary epithelial tumor cells. J. Biol. Chem. 274, 5443-5453.

Wu, R. J. and Zhou, F. Z. (2004). [Insulin-like growth factor II and its receptor gene expression in the endometrium of women with unexplained infertility]. Zhonghua Fu Chan Ke Za Zhi 39, 242-245.

Xi, G., Maile, L. A., Yoo, S. E. and Clemmons, D. R. (2008). Expression of the human beta3 integrin subunit in mouse smooth muscle cells enhances IGF-Istimulated signaling and proliferation. J. Cell. Physiol. 214, 306-315.

Xia, H. F., Jin, X. H., Cao, Z. F., Hu, Y. and Ma, X. (2014a). MicroRNA expression and regulation in the uterus during embryo implantation in rat. FEBS J. 281, 1872-1891.

Xia, H. F., Jin, X. H., Cao, Z. F., Shi, T. and Ma, X. (2014b). MiR-98 is involved in rat embryo implantation by targeting Bcl-xl. FEBS Lett. 588, 574-583.

Yamashiro, S., Yamakita, Y., Ono, S. and Matsumura, F. (1998). Fascin, an actin-bundling protein, induces membrane protrusions and increases cell motility of epithelial cells. Mol. Biol. Cell 9, 993-1006.

Yoon, S. J., Choi, D. H., Lee, W. S., Cha, K. Y., Kim, S. N. and Lee, K. A. (2004) A molecular basis for embryo apposition at the luminal epithelium. Mol. Cell. Endocrinol. 219, 95-104.

Yuan, D. Z., Yu, L. L., Qu, T., Zhang, S. M., Zhao, Y. B., Pan, J. L., Xu, Q., He, Y. P., Zhang, J. H. and Yue, L. M. (2015). Identification and characterization of progesterone- and estrogen-regulated MicroRNAs in mouse endometrial epithelial cells. Reprod. Sci. 22, 223-234.

Zhou, J., Dsupin, B. A., Giudice, L. C. and Bondy, C. A. (1994). Insulin-like growth factor system gene expression in human endometrium during the menstrual cycle. J. Clin. Endocrinol. Metab. 79, 1723-1734. 